\title{
Italian ryegrass cultivars production associated or not with oat black under two post-grazing residues
}

\section{Produção de cultivares de azevém consorciados ou não com aveia preta sob dois resíduos de pastejo}

\author{
Renato Marchesan ${ }^{1 *}$; Wagner Paris ${ }^{2}$; Luis Fernando Glasenapp de Menezes²; \\ Roniclei Tonion ${ }^{3}$; Clederson Martinello ${ }^{3}$; Oelyton Nunes de Oliveira ${ }^{3}$; \\ Sarah Maria Hoppen ${ }^{3}$
}

\begin{abstract}
The objective of this study was to define the input height to grazing and evaluate forage production of Italian ryegrass (Lolium multiflorum Lam.) cv. Barjumbo and cv. Common associated or not with oat black forage (Avena strigosa Schreb) cv. IAPAR 61, submitted to two post-grazing. Treatments consisted of a $4 \times 2$ factorial design, totaling eight treatments with three replications, being evaluated common and Barjumbo ryegrass, single and mixed with black oat in two highs of post-grazing residue: High: $50 \%$ of input height; Low: $30 \%$ of input height. Single Common ryegrass and combined with black oat obtained higher production than Barjumbo cultivate, and greater accumulation rate only when intercropped with black oat. Leaf blades production did not differ among cultivars. Stems production was low to Barjumbo cultivar. Black oat production was higher when associated with Barjumbo. Input height to Italian ryegrass cultivars with $95 \%$ light interception was $26.86 \mathrm{~cm}$ to Barjumbo and $28.75 \mathrm{~cm}$ to common cultivar, and when combined with black oat $34.01 \mathrm{~cm}$ and $32.48 \mathrm{~cm}$, respectively.
\end{abstract}

Key words: Avena strigosa Schreb. Barjumbo. Stem. Leaf blade. Lolium multiflorum.

\section{Resumo}

O objetivo deste estudo foi definir a altura de entrada para pastejo e avaliar a produção de forragem do azevém (Lolium multiflorum Lam.) cv. Barjumbo e do azevém comum (Lolium multiflorum) consorciados ou não com aveia (Avena strigosa Schreb) cv. IAPAR 61 submetidos a resíduos de pastejo. Os tratamentos foram constituídos de um bifatorial $4 \times 2$, totalizando oito tratamentos com três repetições, sendo avaliados os azevém comum e Barjumbo solteiros e consorciados com aveia preta em duas alturas de resíduo pós-pastejo: Alto: 50\% da altura de entrada; Baixo: 30\% da altura de entrada. O azevém comum solteiro e no consórcio com aveia obteve maior produção que o cultivar Barjumbo, e maior taxa de acúmulo apenas quando consorciado com aveia. A produção de folhas não diferenciou entre os cultivares, apenas a produção de colmo que foi menor para o cultivar Barjumbo. A produção de aveia foi maior quando consorciada com o cultivar Barjumbo. A altura de entrada para os cultivares de azevém com $95 \%$ de interceptação luminosa foi de $26,86 \mathrm{~cm}$ para o Barjumbo e $28,75 \mathrm{~cm}$ para o comum, e quando consorciados com aveia de $34,01 \mathrm{~cm}$ e $32,48 \mathrm{~cm}$, respectivamente.

Palavras-chave: Avena strigosa Schreb. Barjumbo. Colmo. Lâmina foliar. Lolium multiflorum.

\footnotetext{
${ }^{1}$ M.e em Zootecnia, Universidade Tecnológica Federal do Paraná, UTFPR, Campus Dois Vizinhos, Dois Vizinhos, PR, Brasil. E-mail: renatomarchesan@yahoo.com.br

2 Profs. Drs., UTFPR, Campus Dois Vizinhos, Dois Vizinhos, PR, Brasil. E-mail: wagparis@yahoo.com.br, luismenezes@utfpr.edu.br

3 Zootecnistas, UTFPR, Campus Dois Vizinhos, Dois Vizinhos, PR, Brasil. E-mail: roniiclei@hotmail.com; cleder.martinello@, gmail.com; oelyton@hotmail.com; sarah.hoppen@hotmail.com

* Author for correspondence
} 


\section{Introduction}

In Brazil, most of cattle production is pasturegrazed. The advantages of using pastures in ruminant production is their low cost, since the animal itself does the forage harvesting, making the conversion of vegetable protein into animal protein, which has higher biological value. However, it is necessary to properly pasture management, maintaining productive potential and nutritional quality, respecting animal requirements (OLIVO et al., 2009). In southern Brazil, among practices that can be adopted to increase animal productivity in pasture, is used cool-season pastures, which when well managed are shown economically viable (SOARES; RESTLE, 2002).

Italian ryegrass cv. common is one of the species most commonly used in these systems, mainly because of natural reseeding convenience, disease resistance, high productive potential and the possibility of intercropping with other species. Thus, Italian ryegrass consortium with black oat aims to associate the two species production peaks, which happen in different periods, extending the grazing period (ROCHA et al., 2007), thus reducing seasonality in forage availability.

Common ryegrass production also varies with its management, as verified by Pontes et al. (2004) who observed different forage mass production, handling at different times, checking that swards grazed at 20 $\mathrm{cm}\left(3,600 \mathrm{~kg} \mathrm{ha}^{-1}\right)$ disclosed higher mass production when compared with heights of 15,10 and $5 \mathrm{~cm}$ $\left(2,400,2,200\right.$ and $920 \mathrm{~kg} \mathrm{ha}^{-1}$, respectively). Italian ryegrass is a grass that can assume two pruning levels $(2 \mathrm{n}=2 \mathrm{x}=14$ chromosomes or $2 \mathrm{n}=4 \mathrm{x}=$ 28 chromosomes), what determines different characteristics, both phenotypic and genotypic. This chromosomes duplication affects plant performance because there is an increase in cell volume (BALOCCHI; LÓPEZ, 2009).

Therefore, rises water content, soluble carbohydrates, proteins and lipids, which increases plant digestibility and, consequently, rumen efficiency and animal performance (SMITH et al., 2001). Thus, some producers are already using tetraploid cultivars, which present some different characteristics from diploid ryegrass, such as initial rapid production and total mass high production, in addition to having a longer growing season compared to diploid cultivars (FARINATTI et al., 2006).

The grazing to rotational stocking is given when it reaches $95 \%$ of light interception by forage canopy, being this the point where there is maximum forage accumulation rate (SILVA, 2015). The grazing animal output point is more flexible and may vary according to grazing purpose, opting for higher animal performance or greater production per hectare (DIFANTE et al., 2009).

The objective of this study was to evaluate Italian ryegrass production (Lolium multiflorum Lam.) cv. Barjumbo and cv. Common associated or not with black oat (Avena strigosa Schreb) cv. IAPAR 61 under two post-grazing residues.

\section{Material and Methods}

The work was conducted from April to September 2012 in Federal Technological University of Paraná - Campus Dois Vizinhos, with an altitude of $520 \mathrm{~m}$, latitude $25^{\circ} 44^{\prime}$ South and longitude $54^{\circ} 04^{\prime}$ ' West, where the climate is mesothermal humid subtropical (Cfa), according to Köppen classification (ALVARES et al., 2013). The soil belongs to red distroferric Nitosol mapping unit, clayey, wavy relief (BHERING; SANTOS, 2008). Precipitation and maximum and minimum temperatures during the experiment period are shown in Figure 1, according to data from National Institute of Meteorology weather station (INMET, 2012). As can be seen, in August there was a severe rainfall restriction, which leaded the analysis to be completed in September.

In April 2012, the species were seeding carried out manually haul with use of closed harrow to 
cover the seeds. Seeding density used was 20 $\mathrm{kg} \mathrm{ha}^{-1}$ of viable seeds of Barjumbo ryegrass, 30 $\mathrm{kg} \mathrm{ha}^{-1}$ of viable seeds of Common ryegrass and $50 \mathrm{~kg} \mathrm{ha}^{-1}$ of oat viable seeds cv. IAPAR 61 to intercropping treatments. Soil chemical analysis of the experimental field and subsequent correction were performed. Nitrogen fertilization used was $150 \mathrm{~kg} \mathrm{ha}^{-1} \mathrm{~N}$, divided into three applications, after the first three grazing.

Figure 1. Precipitation and maximum and minimum temperature in the city of Dois Vizinhos, Paraná, from April to September 2012 (INMET, 2012).

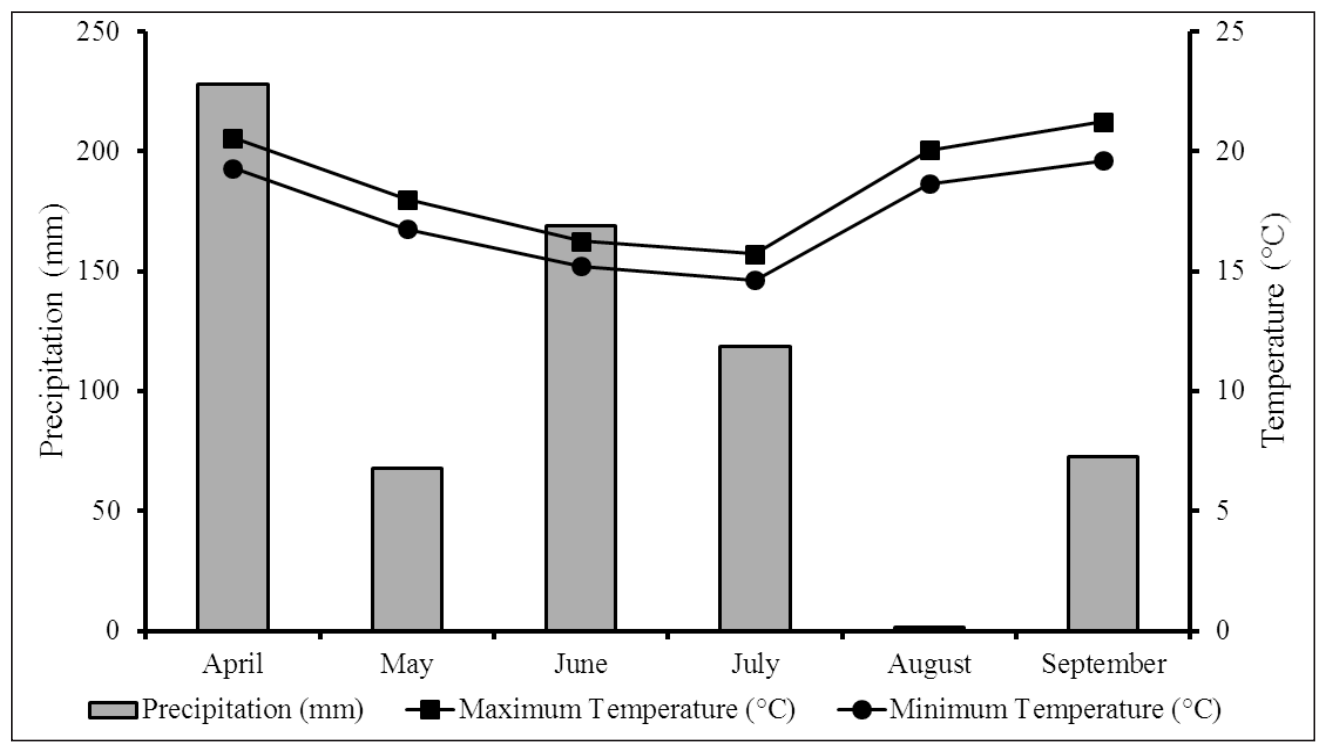

We evaluated Common and Barjumbo ryegrass, singles and mixed with black oat in two postgrazing heights: High: $50 \%$ of input height; Low: $30 \%$ of input height. Treatments consisted of a $4 \times 2$ factorial (species $\mathrm{x}$ post-grazing heights), distributed in a randomized block design with three replications. The area was divided into paddocks of $150 \mathrm{~m}^{2}$ each, using electric fence.

Jersey cows were used for grazing until the desired height (high and low). Time in which animals were kept in pasture varied with post-grazing recommended. Animals entry was conducted at the time that the grazing reached $95 \%$ of light interception (LI). The determination of LI and leaf area index were undertaken with canopy analysis instrument model SunScan Type SS1-COM-R4, through 10 readings per paddock. Pasture height was measured at 10 random points by using picket-graduated ruler.
Variables analyzed were pasture height to $95 \%$ light interception, leaf area index, forage yield, Italian ryegrass production (total, leaf blade and stem), oat production (total, leaf blade and stem), daily accumulation rate and grazing interval.

To evaluate variables were performed three material collections by paddock. Cuts were made close to the ground before and after animals input and output, with scissors and a square of $0.25 \mathrm{~m}^{2}$. Upon removal and homogenized, the sampling was divided in two, being one to dry matter determination in oven with forced ventilation $\left(55^{\circ} \mathrm{C}\right)$ and the other was subjected to botanical separation (Common ryegrass, Barjumbo ryegrass and oat black pasture) and structural components (leaf blade, stem and senescent material) of their components to determine forage yield of different species and plant constituents. 
Forage yield were determined by forage mass difference pre-grazing and post-grazing from previous period. The value reached was divided by the number of days of grazing intervals to determine daily accumulation rates.

Obtained data underwent variance analysis and was applied " $t$ " test at $5 \%$ error probability to average comparison of the experimental period, using SAS software (2011).

\section{Results and Discussion}

It was not observed interaction between cultivar $\mathrm{x}$ height factors. However, there was noticed difference between the evaluated cultivars to forage total yield, and Common ryegrass had higher production than Barjumbo ryegrass, both single and in consortium with black oat (Table 1). Despite expectations of higher production to Barjumbo cultivar, this didn't happen due to water restriction that occurred in the experimental period, especially in the months of August and September (Figure 1), which has deadpan this species potential production, as Barjumbo ryegrass produced significant forage mass until the months of October and November (FARINATTI et al., 2006). Barjumbo ryegrass is a kind of tetraploid Italian ryegrass developed in order to achieve greater productivity, longer growing season, higher proportion of leaf blades and better nutritional quality (DORS, 2009). However, it is observed that Barjumbo ryegrass has less resistance to droughts than common cultivar.

Table 1. Total dry matter yield and daily accumulation from two cultivars of Italian ryegrass (Common and Barjumbo cultivars) associated or not with oat black forage under two post-grazing residues.

\begin{tabular}{|c|c|c|c|c|c|c|}
\hline \multirow{3}{*}{ Post-grazing } & \multicolumn{4}{|c|}{ Total Dry Matter Yield $\left(\mathrm{kg} \mathrm{ha}^{-1}\right)$} & \multirow{3}{*}{ Average } & \multirow{3}{*}{$\mathrm{VC}(\%)$} \\
\hline & \multicolumn{2}{|c|}{ Barjumbo ryegrass } & \multicolumn{2}{|c|}{ Common ryegrass } & & \\
\hline & Single & Consorted & Single & Consorted & & \\
\hline High & 4818 & 4971 & 6939 & 7125 & 5963 & 11.43 \\
\hline Low & 4491 & 5227 & 6562 & 7269 & 5887 & \\
\hline \multirow[t]{2}{*}{ Average } & $4654 \mathrm{~b}$ & $5099 \mathrm{~b}$ & $6751 \mathrm{a}$ & $7197 \mathrm{a}$ & & \\
\hline & \multicolumn{4}{|c|}{ Daily Accumulation Rate $\left(\mathrm{kg} \mathrm{ha}^{-1}\right.$ day $\left.^{-1}\right)$} & & \\
\hline \multirow[t]{2}{*}{ Post-grazing } & \multicolumn{2}{|c|}{ Barjumbo ryegrass } & \multicolumn{2}{|c|}{ Common ryegrass } & Average & $\mathrm{VC}(\%)$ \\
\hline & Single & Consorted & Single & Consorted & & \\
\hline High & 57.1 & 40.7 & 66.8 & 59.1 & $55.9 \mathrm{~A}$ & 12.62 \\
\hline Low & 42.3 & 43.3 & 47.6 & 56.7 & $47.6 \mathrm{~B}$ & \\
\hline Average & $49.7 \mathrm{ab}$ & $42.0 \mathrm{~b}$ & $57.2 \mathrm{a}$ & $58.0 \mathrm{a}$ & & \\
\hline
\end{tabular}

High: output with $50 \%$ of input height; Low: output with $30 \%$ of input height.

Averages followed by different letters differ in the lower row and column statistically differ by " $t$ " test $(p<0.05)$.

Some variables in this study had results affected by water deficit in the period, that is because, according to Kaiser (1987), water deficit cause stoppage of photosynthesis due to $\mathrm{CO}_{2}$ entering decrease in plants. This occurs because of turgidity reduction in leaf stoma guard cells, causing pores closure (SILVA et al., 2001), since these stomata act in $\mathrm{CO}_{2}$ inlet regulation and water loss through transpiration.

Rocha et al. (2007) evaluating black oat and Italian ryegrass mixture on production and quality, based on two established methods, found total forage yield average of 7,444 $\mathrm{kg} \mathrm{DM} \mathrm{ha-1}$, which is a similar result to that from Common ryegrass 
with black oat intercropping, presented in this work. Flores et al. (2008a), evaluating forage production of Common ryegrass populations in Rio Grande do Sul state, observed single Common ryegrass total production of 5,166 $\mathrm{kg} \mathrm{DM} \mathrm{ha}^{-1}$.

Post-grazing height did not differ to total forage production (Table 1). Fact that proves that even at grazing being lowered to a lower height $30 \%$ of input height), it can provide the same production over its cycle, most likely by good soil fertility and nitrogen fertilization, which was performed after the first three collections, period that run-up water restriction. Bortolo et al. (2001) neither found difference in total forage production evaluating coastcross pasture under eight different residual levels. A similar result was found by Marcelino et al. (2006), which reported no difference in marandu grass yield under two grazing intensities (10 and $20 \mathrm{~cm})$.

It was observed effect between treatments for daily accumulation rate in which Common ryegrass (single and intercropped) submitted higher rates than Barjumbo ryegrass intercropped with black oat, but were statistically similar to Single Barjumbo ryegrass (Table 1). This reduced Barjumbo ryegrass accumulation rate, intercropped with black oat. Comparing single Italian ryegrass cultivars, it is not noticed difference probably because leaf area index neither presented any difference. This happens because leaf blade recovery after grazing depends largely on the remaining leaf area (ROCHA et al., 2007). Pellegrini et al. (2010) evaluating Common ryegrass production and quality, subjected to nitrogen fertilization under grazing by sheep, observed average values of $48.7 \mathrm{~kg} \mathrm{DM} \mathrm{ha}^{-1}$ day $^{-}$ 1. Ribeiro et al. (2009) in Italian ryegrass pasture with sheep grazing, found average $58.4 \mathrm{~kg}$ DM $\mathrm{ha}^{-1}$ day $^{-1}$. The accumulation rate reached in this experiment, and setting a forage allowance of $6 \mathrm{~kg}$ DM $100 \mathrm{Kg} \mathrm{LW}^{-1}$ day $^{-1}$, it is possible to calculate stocking. In this sense, we have stocking support to single Barjumbo cultivar of $1,452 \mathrm{~kg} \mathrm{LW} \mathrm{ha}{ }^{-1}$, and $1,197 \mathrm{~kg} \mathrm{LW} \mathrm{ha}^{-1}$ in the consortium. Common ryegrass has higher stocking supports, both single and intercropped, with 1,970 and 1,590 $\mathrm{kg} \mathrm{LW} \mathrm{ha}^{-1}$, respectively.

Greater accumulation rate was observed to postgrazing height ( $50 \%$ of input height). Thus, this result shows that the highest residue provides more photosynthetic active leaf blades, which provides a higher accumulation rate. In a study by Flores et al. (2008b), the authors checked out similar results on marandu grass and xaraes grass, where most post-grazing height $(40 \mathrm{~cm})$ disclosed higher accumulation rate than $15 \mathrm{~cm}$ height.

Single Common ryegrass featured higher yield than the other treatments (Table 2). In treatments where there is intercropping, logically production was lower because it was production of single ryegrass, isolating from oat production. This is because plants compete in for resources such as light, water and nutrients (ZANINE; SANTOS, 2004). However, it is realized that Common ryegrass, when intercropping, presented greater production than intercropped Barjumbo ryegrass and the same production that single Barjumbo ryegrass. Flores et al. (2008a), evaluating different Italian ryegrass germplasm, discovered productions of 5,166, 4,773 and 6,349 $\mathrm{kg} \mathrm{DM} \mathrm{ha}^{-1}$ for common cultivar, San Gabriel and Sarandi respectively. Goral et al. (2013), evaluating forage yield of oat and Italian ryegrass cultivars under nitrogen fertilization, found not difference in production to Common and Barjumbo cultivars (5,263 and 5,037 kg DM ha-1, respectively).

Leaf blade yield to single Barjumbo ryegrass was similar to Single Common ryegrass (Table 2), demonstrating Barjumbo ryegrass great potential, because even in a water restriction period exhibited substantial yield leaf blade, which is desirable for display better quality than the stem, being able to provide greater animal performance. In intercropping treatment, production was lower, which was expected due to black oat participation. 
Table 2. Total yield (leaf blade + stem), leaf blade and stem production of two cultivars (Common and Barjumbo) of Italian ryegrass associated or not with oat black forage under two post-grazing residues.

\begin{tabular}{|c|c|c|c|c|c|c|}
\hline \multirow{3}{*}{ Post-grazing } & \multicolumn{4}{|c|}{ Total Italian Ryegrass Yield $\left(\mathrm{kg} \mathrm{ha}^{-1}\right)$} & \multirow{3}{*}{ Average } & \multirow{3}{*}{$\mathrm{CV}(\%)$} \\
\hline & \multicolumn{2}{|c|}{ Barjumbo ryegrass } & \multicolumn{2}{|c|}{ Common ryegrass } & & \\
\hline & Single & Consorted & Single & Consorted & & \\
\hline High & 4900 & 1660 & 6609 & 4052 & 4305 & 21.19 \\
\hline Low & 4442 & 1302 & 6902 & 5399 & 4511 & \\
\hline \multirow[t]{2}{*}{ Average } & $4671 \mathrm{~b}$ & $1481 \mathrm{c}$ & $6756 \mathrm{a}$ & $4725 \mathrm{~b}$ & & \\
\hline & \multicolumn{4}{|c|}{ Italian Ryegrass Leaf Blade yield $\left(\mathrm{kg} \mathrm{ha}^{-1}\right)$} & & \\
\hline \multirow[t]{2}{*}{ Post-grazing } & \multicolumn{2}{|c|}{ Barjumbo ryegrass } & \multicolumn{2}{|c|}{ Common ryegrass } & Average & $\mathrm{CV}(\%)$ \\
\hline & Single & Consorted & Single & Consorted & & \\
\hline High & 4460 & 1482 & 4008 & 1459 & 2852 & 23.66 \\
\hline Low & 4186 & 1214 & 4148 & 3162 & 3177 & \\
\hline \multirow[t]{2}{*}{ Average } & $4323 \mathrm{a}$ & $1348 \mathrm{c}$ & $4078 \mathrm{a}$ & $2311 \mathrm{~b}$ & & \\
\hline & \multicolumn{4}{|c|}{ Italian Ryegrass Stem Yield $\left(\mathrm{kg} \mathrm{ha}^{-1}\right)$} & & \\
\hline \multirow[t]{2}{*}{ Post-grazing } & \multicolumn{2}{|c|}{ Barjumbo ryegrass } & \multicolumn{2}{|c|}{ Common ryegrass } & Average & $\mathrm{CV}(\%)$ \\
\hline & Single & Consorted & Single & Consorted & & \\
\hline High & 440 & 178 & 2601 & 2593 & 1453 & 25.28 \\
\hline Low & 257 & 88 & 2754 & 2237 & 1334 & \\
\hline Average & $348 \mathrm{~b}$ & $133 \mathrm{~b}$ & $2678 \mathrm{a}$ & $2415 \mathrm{a}$ & & \\
\hline
\end{tabular}

High: output with $50 \%$ of input height; Low: output with $30 \%$ of input height.

Averages followed by different letters differ in the lower row and column statistically differ by " $\mathrm{t}$ ” test $(\mathrm{p}<0.05)$.

Stem yield was higher to Common ryegrass, both single and intercropped, further reinforcing the concept that Barjumbo ryegrass has great potential. It produced around 93\% leaf blade when single, and 91\% intercropped, while single Common ryegrass produced approximately $60 \%$ leaf blades and $49 \%$ intercropped. Leaf blade proportions found by Flores et al. (2008a) were approximately 35, 49 and $51 \%$ to common cultivars, San Gabriel and Sarandi respectively, which are similar to Common ryegrass proportions in this work. Similar to these values, Bratti et al. (2009) observed about 53\% leaf blades to Common ryegrass.

Among the different heights of post-grazing residue, there were no differences in leaf blade and stem yield to Italian ryegrass (Table 2). This result was because there was no LAI difference between different heights, which provided a similar regrowth. Cutrim Junior et al. (2011) checked similar results assessing Tanzania grass canopy structural characteristics, submitted to three defoliation frequencies and two post-grazing residues. They found no difference in leaf blades and stem yield.

In variables related to black oat (total, leaf blade and stem yield) was observed difference between treatments (Table 3), and black oat, when intercropped with Barjumbo ryegrass, presented higher production in both variables. This difference is attributed to the fact that Barjumbo ryegrass yield was lower. Thus, black oat could develop better because in the forage canopy plants compete for environment resources (light, water, nutrients, etc.) (ZANINE; SANTOS, 2004). In addition, Common ryegrass demonstrated to have allelopathic effect on other plants, that is, damaging their development (MORAES et al., 2009). Demétrio et al. (2012), evaluating oat cultivars yield, under different cut managements, discovered higher values to single black oat cv. IAPAR $61\left(4,397 \mathrm{~kg} \mathrm{ha}^{-1}\right)$. 
To different post-grazing residue heights, none of the variables related to black oat showed significant differences. This was because it was not observed difference in LAI between heights, thus the plants, even being demoted to lower height, still contained sufficient amount of leaf blade to conduct photosynthesis and allow a good regrowth.

Table 3. Total yield (leaf blade + stem), leaf blade and stem production of oat black forage intercropped with Italian ryegrass Barjumbo or Common cultivars under two post-grazing residues.

\begin{tabular}{|c|c|c|c|c|}
\hline \multirow{2}{*}{ Post-grazing } & \multicolumn{2}{|c|}{ Total Oat Production $\left(\mathrm{kg} \mathrm{ha}^{-1}\right)$} & \multirow{2}{*}{ Average } & \multirow{2}{*}{$\mathrm{CV}(\%)$} \\
\hline & Barjumbo ryegrass & Common ryegrass & & \\
\hline High & 3491 & 2960 & 3225 & 25.72 \\
\hline Low & 3928 & 1851 & 2889 & \\
\hline Average & $3709 \mathrm{a}$ & $2406 \mathrm{~b}$ & & \\
\hline \multirow{2}{*}{ Post-grazing } & \multicolumn{2}{|c|}{ Oat Black Leaf Blade $\left(\mathrm{kg} \mathrm{ha}^{-1}\right)$} & Average & $\mathrm{CV}(\%)$ \\
\hline & Barjumbo ryegrass & Common ryegrass & Average & $C(\%)$ \\
\hline High & 2267 & 1872 & 2069 & 16.76 \\
\hline Low & 2473 & 1499 & 1986 & \\
\hline Average & $2370 \mathrm{a}$ & $1686 \mathrm{~b}$ & & \\
\hline \multirow{2}{*}{ Post-grazing } & \multicolumn{2}{|c|}{ Oat Black Stem $\left(\mathrm{kg} \mathrm{ha}^{-1}\right)$} & Averaoe & $\mathrm{CV}(\%)$ \\
\hline & Barjumbo ryegrass & Common ryegrass & & $C(\%)$ \\
\hline High & 1224 & 1088 & 1156 & 38.86 \\
\hline Low & 1455 & 352 & 904 & \\
\hline Average & $1339 \mathrm{a}$ & $720 \mathrm{~b}$ & & \\
\hline
\end{tabular}

High: output with $50 \%$ of input height; Low: output with $30 \%$ of input height.

Averages followed by different letters differ in the lower row and column statistically differ by "t" test $(p<0.05)$.

Grazing input height presented treatments effect. It was verified that intercropped treatments had higher input heights than treatments with single Italian ryegrass (Table 4). This is due to black oat presence, since it requires a greater height to achieve $95 \%$ of light interception. However, Bratti et al. (2009), evaluating Common ryegrass and black oat, in single culture and intercropped, detected no difference in input heights of Common ryegrass $(40.51 \mathrm{~cm})$ and intercropped with black oat $(40.26 \mathrm{~cm})$. Nevertheless, Embrapa Dairy Cattle (EMBRAPA, 2013) recommends entry to Italian ryegrass grazing with a height of around 20 $\mathrm{cm}$ and black oat 25 to $30 \mathrm{~cm}$.

Leaf area index (LAI) did not differ among treatments. This help to explain why there was a difference in input heights between treatments, demonstrating that both Barjumbo and Common ryegrass reach the $95 \%$ of light interception with a height lower than black oat.

Leaf area index are consistent with Welch (1995), which said LAI close to 4 to winter cereals allows to intercept more than $95 \%$ of incident radiation. Also in this context, Lemerle et al. (2004) state that when LAI is increased, biomass production raises until there leaf blades self-shadowing occurs, hence the average photosynthetic rate per unit leaf area decreases.As for the treatments, post-grazing residue heights did not affect LAI. Cutrim Junior et al. (2011) verified the same in Tanzania grass assessment, submitted to three frequencies of defoliation and two post-grazing residues. 
To grazing interval variable, it was observed difference between treatments (Table 4), where single Common ryegrass disclosed lower grazing interval, for having presented a good daily accumulation rate (Table 1) combined with reaching animals input point with a smaller height when compared to treatments with black oat presence. The greater range of grazing was observed in Barjumbo ryegrass intercropped, probably due to the lowest rate of daily accumulation, and by Barjumbo ryegrass has not presented a good production yield. Tonato et al. (2014) conducted a study with black oat pasture and Italian ryegrass light interception and uncovered that single Common ryegrass cutting interval was of 18 days, but when it was intercropped with black oat this range rose to 23.7 days, and finally the single oat presented 32.3 days interval.

Table 4. Input height to grazing, leaf area index and interval between grazing of two cultivars (Common and Barjumbo) of Italian ryegrass associated or not with oat black forage under two post-grazing residues, standardized to $95 \%$ light interception.

\begin{tabular}{|c|c|c|c|c|c|c|}
\hline \multirow{3}{*}{ Post-grazing } & \multicolumn{4}{|c|}{ Input Height (cm) } & \multirow{3}{*}{ Average } & \multirow{3}{*}{$\mathrm{CV}(\%)$} \\
\hline & \multicolumn{2}{|c|}{ Barjumbo ryegrass } & \multicolumn{2}{|c|}{ Common ryegrass } & & \\
\hline & Single & Consorted & Single & Consorted & & \\
\hline High & 27.18 & 33.53 & 28.60 & 33.58 & 30.72 & 5.05 \\
\hline Low & 26.53 & 34.48 & 28.91 & 31.38 & 30.32 & \\
\hline Average & $26.86 \mathrm{~b}$ & $34.01 \mathrm{a}$ & $28.75 \mathrm{~b}$ & $32.48 \mathrm{a}$ & & \\
\hline \multirow{3}{*}{ Post-grazing } & \multicolumn{4}{|c|}{ Leaf Area Index } & \multirow{3}{*}{ Average } & \multirow{3}{*}{$\mathrm{CV}(\%)$} \\
\hline & \multicolumn{2}{|c|}{ Barjumbo ryegrass } & \multicolumn{2}{|c|}{ Common ryegrass } & & \\
\hline & Single & Consorted & Single & Consorted & & \\
\hline High & 4.81 & 4.50 & 5.02 & 4.49 & 4.70 & 6.17 \\
\hline Low & 4.53 & 4.75 & 4.68 & 4.97 & 4.73 & \\
\hline \multirow[t]{2}{*}{ Average } & 4.67 & 4.62 & 4.85 & 4.73 & & \\
\hline & \multicolumn{4}{|c|}{ Interval Between Grazing (days) } & \multirow{3}{*}{ Average } & \multirow{3}{*}{$\mathrm{CV}(\%)$} \\
\hline \multirow[t]{2}{*}{ Post-grazing } & \multicolumn{2}{|c|}{ Barjumbo ryegrass } & \multicolumn{2}{|c|}{ Common ryegrass } & & \\
\hline & Single & Consorted & Single & Consorted & & \\
\hline High & 30.00 & 35.00 & 22.03 & 28.90 & 28.98 & 6.48 \\
\hline Low & 29.30 & 34.00 & 24.27 & 26.93 & 28.63 & \\
\hline Average & $29.65 \mathrm{~b}$ & $34.50 \mathrm{a}$ & $23.15 \mathrm{c}$ & $27.92 \mathrm{~b}$ & & \\
\hline
\end{tabular}

High: output with $50 \%$ of input height; Low: output with $30 \%$ of input height.

Averages followed by different letters differ in the lower row and column statistically differ by " $\mathrm{t}$ " test $(\mathrm{p}<0.05)$.

Post-grazing output times did not influence the interval between grazing even with the greatest daily accumulation rate to output time in $50 \%$ (Table 1). Cutrim Junior et al. (2011), comparing two LAI post-grazing residues (1.0 and 1.8), observed larger intervals between grazing to the lowest LAI, i.e. for treatment with lower height post-grazing.

\section{Conclusions}

Common ryegrass presents higher forage yield than Barjumbo ryegrass, even when intercropped with black oat cv. IAPAR61 in water restriction conditions, regardless of the post-grazing residue.

Barjumbo presented the same leaf blade production than Common ryegrass and small amount of stem. 
The grazing input height in Barjumbo ryegrass is approximately $27 \mathrm{~cm}$, while the Common ryegrass lies around $29 \mathrm{~cm}$. In consortium with black oat, Barjumbo ryegrass input height is around $34 \mathrm{~cm}$ and of the Common cultivar is approximately $32.5 \mathrm{~cm}$.

\section{Acknowledgments}

On Coordination of Higher Education Personnel (CAPES), for granting master's level of scholarship to the first author.

\section{References}

ALVARES, C. A.; STAPE, J. L.; SENTELHAS, P. C.; GONÇALVES, J. L. M.; SPAROVEK, G. Köppen's climate classification map for Brazil. Meteorologishe Zeitschrift, Stuttgart, v. 22, n. 6, p. 711-728, 2013.

BALOCCHI, O. A.; LÓPEZ, I. L. Herbage production, nutritive value and grazing preference of diploid and tetraploid perennial ryegrass cultivars (Lolium perenne L.). Chilean Journal of Agricultural Research, Chillán, v. 69, n. 3, p. 331-339, 2009.

BHERING, S. B.; SANTOS, H. G. Mapa de solos do Estado do Paraná: legenda atualizada. Rio de Janeiro: EMBRAPA/IAPAR, 2008. 74 p.

BORTOLO, M.; CECATO, U.; MARTINS, E. N.; CANO, C. C. P.; COALHO, M. G.; CANTO, M. W.; SANTOS, G. T. Avaliação de uma pastagem de Coastcross-1 (Cynodon dactylon (1.) pers) sob diferentes níveis de matéria seca residual. Revista Brasileira de Zootecnia, Viçosa, MG, v. 30, n. 3, p. 627-635, 2001.

BRATTI, L. F. S.; DITTRICH, J. R.; BARROS, C. S.; SILVA, C. J. A.; MONTEIRO, A. L. G.; ROCHA, C.; ROCHA, F. M. P. Comportamento ingestivo de caprinos em pastagem de azevém e aveia-preta em cultivo puro e consorciado. Ciência Animal Brasileira, Goiânia, v. 10, n. 2, p. 397-405, 2009.

CUTRIM JUNIOR, J. A. A.; CÂNDIDO, M. J. D.; VALENTE, B. S. M.; CARNEIRO, M. S. S.; CARNEIRO, H. A. V. Características estruturais do dossel de capim-tanzânia submetido a três frequências de desfolhação e dois resíduos pós-pastejo. Revista Brasileira de Zootecnia, Viçosa, MG, v. 40, n. 3, p. 489497, 2011.
DEMÉTRIO, J. V.; COSTA, A. C. T.; OLIVEIRA, P. S. R. Produção de biomassa de cultivares de aveia sob diferentes manejos de corte. Pesquisa Agropecuária Tropical, Goiânia, v. 42, n. 2, p. 198-205, 2012.

DIFANTE, G. S.; EUCLIDES, V. P. B.; NASCIMENTO JUNIOR, D.; SILVA, S. C.; TORRES JUNIOR, R. A. A.; SARMENTO, D. O. L. Ingestive behaviour, herbage intake and grazing efficiency of beef cattle steers on Tanzania guineagrass subjected to rotational stocking managements. Revista Brasileira de Zootecnia, Viçosa, MG, v. 38, n. 6, p. 1001-1008, 2009.

DORS, C. A. Suscetibilidade dos genótipos diplóides e tetraplóides de azevém (Lolium multiflorum Lam.) ao herbicida glyphosate. 2009. Dissertação (Mestrado em Agronomia) - Universidade de São Paulo, Piracicaba.

EMPRESA BRASILEIRA DE PESQUISA AGROPECUÁRIA - EMBRAPA Gado de leite. Utilização de aveia e azevém. Juiz de Fora: Infoteca-E, 2013. Disponível em: <https://www.agencia.cnptia. embrapa.br/recursos/Suplementao Aveia AzevemIDpMUEdZByUo.pdf $>$. Acesso em: $1 \overline{6}$ jun. 2016.

FARINATTI, L. H. E.; BRONDANI, I. L.; RESTLE, J.; CHIEZA, E. D.; ARBOITTE, M. Z.; KOEFENDER, I.; CATTELAN, J.; CEZIMBRA, J. M.; CHASSOT, R. C. Avaliação de diferentes cultivares de azevém no desempenho de bezerros. Santa Maria: Embrapa Clima Temperado, 2006. 16 p. (Documento, 166).

FLORES, R. A.; DALL'ANGNOL, M.; NABINGER, C.; MONTARDO, D. P. Produção de forragem de populações de azevém anual no estado do Rio Grande do Sul. Revista Brasileira de Zootecnia, Viçosa, MG, v. 37, n. 7, p. 1168-1175, 2008a.

FLORES, R. S.; EUCLIDES, V. P. B.; ABRÃO, M. P. C.; GALBEIRO, S.; DIFANTE, G. S.; BARBOSA, R. A. Desempenho animal, produção de forragem e características estruturais dos capins marandu e xaraés submetidos a intensidades de pastejo. Revista Brasileira de Zootecnia, Viçosa, MG, v. 37, n. 8, p. 1355-1365, 2008 b.

GORAL, A. L.; LUGOCH, M. L.; DALCIN, V.; GÜTHS, F. L. V.; SZARESKI, V. J.; CARAFFA, M. Desempenho forrageiro de cultivares de aveia e azevém com duas doses de adubação nitrogenada nas condições de clima e solo de Giruá, RS, 2012. In: REUNIÃO DA COMISSÃO BRASILEIRA DE PESQUISA DE AVEIA, 33., 2013, Pelotas. Anais... Pelotas: PCBPA, 2013.

INSTITUTO NACIONAL DE METEOROLOGIA - INMET. Consulta dados da estação automática. Dois Vizinhos: [s.n.], 2012. Disponível em: <http:// www.inmet.gov.br/sonabra/pg_dspDadosCodigo. php?QTg0Mw>. Acesso em: 24 out. 2012. 
KAISER, W. M. Effect of water deficit on photosynthetic capacity. Physiologia Plantarum, Copenhagen, v. 71, n. 1, p. 142-149, 1987.

LEMERLE, D.; COUSENS, R. D.; GILL, G. S.; PELTZER, S. J.; MOERKERK, M.; MURPHY, C. E.; COLLINS, D. J.; CULLIS, B. Reliability of higher seeding rates of wheat for increased competitiveness with weeds in low rainfall environments. Journal of Agricultural Science, Cambridge, v. 142, n. 1, p. 395409, 2004.

MARCELINO, K. R. A.; NASCIMENTO JUNIOR, D.; SILVA, S. C.; EUCLIDES, V. P. B.; FONSECA, D. M. Características morfogênicas e estruturais e produção de forragem do capim-marandu submetido a intensidades e frequências de desfolhação. Revista Brasileira de Zootecnia, Viçosa, MG, v. 35, n. 6, p. 2243-2252, 2006.

MORAES, P. V. D.; AGOSTINETTO, D.; VIGNOLO, G. K.; SANTOS, L. S.; PANOZZO, L. E. Manejo de plantas de cobertura no controle de plantas daninhas na cultura do milho. Planta Daninha, Viçosa, MG, v. 27, n. 2, p. 289-296, 2009.

OLIVO, C. J.; ZIECH, M. F.; MEINERZ, G. R.; AGNOLIN, C. A.; TYSKA, D.; BOTH; J. F. Valor nutritivo de pastagens consorciadas com diferentes espécies de leguminosas. Revista Brasileira de Zootecnia, Viçosa, MG, v. 38, n. 8, p. 1543-1552, 2009.

PELLEGRINI, L. G.; MONTEIRO, A. L. G.; NEUMANN, M.; MORAES, A.; PELLEGRINI, A. C. R. S.; LUSTOSA, S. B. C. Produção e qualidade de azevémanual submetido a adubação nitrogenada sob pastejo por cordeiros. Revista Brasileira de Zootecnia, Viçosa, MG, v. 39, n. 9, p. 1894-1904, 2010.

PONTES, L. S.; CARVALHO, P. C. F.; NABINGER, C.; SOARES, A. B. Fluxo de biomassa em pastagem de azevém anual (Lolium multiflorum Lam.) manejada em diferentes alturas. Revista Brasileira de Zootecnia, Viçosa, MG, v. 33, n. 3, p. 529-537, 2004.

RIBEIRO, T. M. D.; MONTEIRO, A. L. G.; POLI, C. H. E. C.; MORAES, A.; SILVA, A. L. P.; BARROS, C. S. Características da pastagem de azevém e produtividade de cordeiros em pastejos. Revista Brasileira de Zootecnia, Viçosa, MG, v. 38, n. 3, p. 580-587, 2009.
ROCHA, M. G.; PEREIRA, L. E. T.; SCARAVELLI, L. F. B.; OLIVO, C. J.; AGNOLIN, C. A.; ZIECH, M. F. Produção e qualidade de forragem da mistura de aveia e azevém sob dois métodos de estabelecimento. Revista Brasileira de Zootecnia, Viçosa, MG, v. 36, n. 1, p. 7-15, 2007.

STATISTICAL ANALYSIS SYSTEM INSTITUTE SAS Institute. SAS/STAT user's guide: statistics. Realse 8. Cary: SAS Institute, 2001. 1292 p.

SILVA, S. C. O manejo do pastejo e a intensificação da produção animal. Caderno de Ciências Agrárias, Montes Claros, v. 7, n. 1, p. 80 -100, 2015.

SILVA, S.; SOARES, A. M.; OLIVEIRA, L. E. M. Respostas fisiológicas de gramíneas promissoras para revegetação ciliar de reservatórios hidrelétricos, submetidos à deficiência hídrica. Ciência e Agrotecnologia, Lavras, v. 25, n. 1, p. 124-133, 2001.

SMITH, K.; SIMPSON, R. J.; CULVENOR, R. A.; HUMPHREYS, M. O.; PRUD'HOMME, M. P.; ORAM, R. N. The effects of ploidy and a phenotype conferring a high water soluble carbohydrate concentration on carbohydrate accumulation, nutritive value and morphology of perennial ryegrass (Lolium perenne). Journal of Agricultural Science, Cambridge, v. 136, n. 1, p. 65-74, 2001.

SOARES, A. B.; RESTLE, J. Produção animal e qualidade de forragem de pastagem de triticale e azevém submetida a doses de adubação nitrogenada. Revista Brasileira de Zootecnia, Viçosa, MG, v. 31, n. 2, p. 908 917, 2002.

TONATO, F.; PEDREIRA, B. C.; PEDREIRA, C. G. S.; PEQUENO, D. N. L. Aveia preta e azevém anual colhidos por interceptação de luz ou intervalo fi xo de tempo em sistemas integrados de agricultura e pecuária no Estado de São Paulo. Ciência Rural, Santa Maria, v. 44, n. 1, p. 104-110, 2014.

WELCH, R. W. The oat crop: production and utilization. London: Chapman \& Hall, 1995. 584 p.

ZANINE, A. M.; SANTOS, A. M. Competição entre espécies de plantas - uma revisão. Revista da FZVA, Uruguaiana, v. 11, n. 1, p. 10-30. 2004. 